\title{
Study on Ecological Compensation Policy among the Micro Subjects on Water Energy Resources Development
}

\author{
Shihua LI ${ }^{1}$, Deshan TANG ${ }^{2}$ \\ ${ }^{1}$ Business school, Hohai University, Nanjing, China \\ ${ }^{2}$ College of Water Conservancy and Hydropower Engineering, Hohai University, Nanjing, China \\ E-mail: Lishihua88@163.com; Lishihua88@sina.com \\ Received December 12, 2008; revised February 6, 2009; accepted February 12, 2009
}

\begin{abstract}
The subjects of ecological compensation involve the nation, society, development enterprises of water-energy resources, as well as the location of resource itself. This paper systematically studies on how to make "water energy sources market compensation policy", "the economic compensation policy for relevant interest subjects" and "the ecological compensation policy of basin ecological water." So, it is necessary to exert the complementary function between market compensation and government compensation by the means of economic compensation and to establish the ecological compensation policy of basin ecological water, which is beneficial to coordinating the stakeholders' interests of cross-region or inter-basin. And it is important and significant to establish constantly perfected ecological compensation policy among the micro subjects on water energy resources development, so as to coordinate interest relationships among various subjects and finally reach the aim of sustainable use of water energy resources and environmental protection as possible.
\end{abstract}

Keywords: Ecological Compensation Policy, Water Energy Resources Development, Micro Subjects, Resource Compensation, Economic Compensation, Regional Ecological Water, Market Compensation, Government Compensation

\section{Introduction}

Ecological compensation is an institutional arrangement regulating interests relation of relevant persons chiefly by economic means for the purpose of protecting and utilizing ecosystem services sustainably. [1] The subjects of ecological compensation include the nation, society, development enterprises of water-energy resources, as well as the location of resource itself. The concrete can be divided into the following categories: state compensation, society compensation and self-compensation. In the exploration of water energy resources, the relevant subjects of interests involve developers of resources, the contemporary interest subjects and the descendant interest subjects. Due to no spokesman for future generations, the responsibilities will naturally fall on the state on behalf of the interests of the descendant interest subjects. Therefore, the internal mechanism of policy analysis is mainly related to the compensation of the hydropower resources for the sustainable use of resources, the economic compensation for the contemporary interest subjects and the ecological environmental compensation for the descendant interest subjects. In China, researches on eco-compensation mainly focuses on forestry [2], "conversion of cropland to forest" [3] and "returning farmland to lake" [4], mineral resource utilization[5], ecocompensation for the regional development [6,7], the compensation mechanism under various policies [8] and so on. With regard to the eco-compensation mechanism of water energy resources development and utilization, the study centers on the compensation policy, including compensation and compensation mechanism of hydraulic engineering [9], the sustainable use of hydropower resources, hydropower market standardization $[10,11]$ and so on. These researches are all having made certain contributions to China's ecological protection in different perspectives. This paper gives comparatively systematic researches on the three ecological compensation policies 
of water energy resources development: resource market compensation; economic compensation; basin ecological water. It may serve as references for the governmental bodies and other social public departments to institute environmental policies, as well as for the stakeholders to solve or coordinate the interest relationships in the water energy resource development. So it will be important theoretically and practically to strengthen this research field, so as to coordinate the interest relationships among micro-subjects, sustainably utilize water energy resources and finally reach the aim of ecological protection as possible.

\section{Resource Market Compensation Policy for Water Energy Resources}

Although it is clearly stipulated in Water Law of PRC that "water resources belong to the state", and "the state carries out water abstraction licensing and paid use of water resources", there is no specific regulations and implementing method for the management of developing and using right for water energy resources. In order to balance the interests among the country, investors and residents and reduce economic losses in water energy resource development, the government should enact the laws and regulations about occupation and utilization of scarce resources, so as to form an opportunity for fair competition as far as possible, rather than the special right for only some enterprises and individuals. It is just by market rules that ecological compensation mechanism becomes one of the best way to rationally settle the relationships among environmental protection, benefits and damages. [12] By market competition mechanism, more and more enterprises can take part in the competition or cooperation of water energy resource development.

\subsection{Exert the Roles of Market Mechanism in Water Energy Resources Development}

In general, there are two forms of compensable transfer of hydropower resources. One is negotiating transfer, which happens only when a few investors take part in the competition. The other is a number of investors for the right to development, the situation when many investors scramble for the right of resource development. The most efficient way is to deploy resources through the mechanism of market competition. That is by public auction to decide the developers. So it is necessary to establish trading market of property rights among the property right subject. In order to obtain the property rights of environmental resource development, transaction subjects will bid against each other, and finally the property right blogs to the highest bidder. The high costs of property rights of environmental resources will inevitably encourage the subject to effectively use and protect the rights, so as to avoid operation of low efficiency and the "external diseconomy" caused by the monopoly of environmental resources property. [13] The fundamental goal of the ecological compensation policy, which involves numerous stakeholders, is to regulate the economic interests of protectors in ecological security. However, in current policy-making process of ecological protection, there is still lack of extensive participation mechanism of stakeholders. Moreover, the current policies embody the will of central government much more than the stakeholders' interests of local government and ecological protection area, which may be divorced from reality and not good for environmental protection. The market compensation, a way of market incentive, includes "pollution charge", "the exchange of environmental property right”, “environmental protection fund”, “environmental liability insurance”, “contract compensation of environmental protection industry", and so on. It is just by the above way that the market mechanism in water energy resources development can embody, as much as possible, the market value of the ecological resources under the government's macro-control. In addition, the diversification of market subjects of environmental property rights will be beneficial to embodying the real value of resources through price lever transferring among various subjects. [14]

\subsection{Deal Well with the Relationships between Market Compensation and Government Compensation}

Certainly, market compensation in the scope of government regulation and control endows the ecological resources with the commodity attributes through the market mechanism, in which the cost of the ecological environment will be incorporated into the subject decision- making so as to make the developer and user of eco-environmental resources bear the corresponding responsibility. Comparing with the government compensation, the market compensation possesses the following shortcomings: the difficulty of compensation; serious short-term behavior for compensation; the lack of relevant laws and regulations. [15] For example [10,11,16], as per the experience of Zhejiang province, to set up an open, fair and just market mechanism of transfer of resources, attention must be paid as the following aspects:

- Before a transfer of resources, the governments do a good plan and master the status of the intra-regional resources. According to the size of the investment, disclosure of information should be issued in the corresponding span of the media, and barriers to entry should be broken in huge investment.

- As for water resources development projects of the comprehensive utilization, in particular, the project 
with flood control and drainage and other social public welfare projects with functions of flood control and drainage, the results of the auction may make the price of developing right "negative". That means national finance needs to put money to investors. In fact, the government's investment plus the transfer price of resources is just equal to the investment of other public welfare projects except the function of power generation. This part should be invested by the government. The "negative" price does not contradict the theory in the market allocation of scarce resources.

- When there are not enough participants in a public auction, the two sides adopt transfer mechanism of the agreement, but a certain amount of resource prices must be reflected. Fundamentally, the possible legal disputes resulting from historical development will be eliminated as possible.

- When the government intends to support investors, it can take the form of resource stock, but the stock right belongs to the state instead of the local residents.

At the initial stage of ecological compensation, it is necessary to exert the guiding function of the government in the process of the establishment of an ecological compensation mechanism, and to improve the input mechanism of public finance for ecological protection. Meanwhile, the multilateral financing channel and market-oriented operation way should be established based on the policies and regulations standardizing and restraining the behavior of the subjects of market economy.

\section{The Economic Compensation Policy for Relevant Interest Subjects}

Although the water energy resources and land resources belong to the country, local residents have the right to use. If the process of water energy resources development involves the problems such as emigration, land expropriation and so on, investors should give financial compensation for local residents. This inevitably involves external problem during the development of hydropower resources. The externality of water energy resources development and utilization refers to the local social, economic and environmental effects caused by the subjects of hydropower construction which will lead to the increase of the cost or benefit. [17] The direction and result of externality show the dual nature, namely "external economy" and "external diseconomies". Those which are able to bring about benefits or the reduction of costs for the society or individuals are called "external economy", while those which are able to decrease the benefits or increase the costs for the society or individuals are called "external diseconomy" or "market failure" [11].

\subsection{Establish a Macro-Level Hydropower Resources Compensation Mechanism}

The compensation mechanism of water energy resources development should be based on the principle of the combination of government regulation and voluntary negotiation. The negative externality of water resources allocation involves three levels. The first level is state in macro-scope. The adjustment of general planning for the whole watershed will make some people damage or benefit. In order to guarantee mass benefit and social stability and protect ecological environment in the reservoir region and its downstream regions, measures of aftercare and compensation should be carried out according to existing laws and regulations as well as policy. These mandatory measures and compensation criterion should be stipulated by state and government. The state should make the ecologic flux of channel, volume standard of water environment, guarantee measures of the minimum water demand per capita and so on.

\subsection{Establish Ecological Compensation Mecha- nism of Water Resources Property Right}

The definition of property right is precondition of compensation mechanism. It is only the clear property right that can determine externality, and the compensation mechanism can come true. But in China, the concept of "water right" was put forward for not a long time. The property rights of water resources should includes ownership, administrative power, use right and management right. The ownership of water resources belongs to the state; the administrative power of water resources belongs to the government; the management right belongs to enterprises. The use right includes the most fundamental use right of residents along the river except for use right obtained by enterprises. Therefore, the income by auction of hydropower resources and negotiating transfer, except the compensation for the state-owned right of water resources, includes the compensation of local residents related to basin water resources.

\subsection{Establish a Micro-Level Hydropower Re- sources Compensation Mechanism}

Because the development of water energy resources affects the interests of other economic subject, such condition belongs to category of micro economy. Thus the compensation measures and standard should be achieved by bilateral negotiation as per severity of influence. At this stage, the negative externality of water resources development should include two levels: There are clear externalities in the feasibility study phase of hydropower resource development; or there are no clear externalities in the feasibility study phase, but accidental occurrence of negative externalities in the operation after water resource development. 


\subsection{Establish Compensation Mechanism for External Economy}

The water energy resources development have a positive economic, ecological and social benefits, including the construction of hydropower stations in remote mountain areas without electricity, raising the standard of flood control in the downstream channel of a hydroelectric station, reducing environmental pollution caused by fuel for power generation, construction of reservoirs guaranteeing the domestic water and the process water of downstream residents, etc. These are properties of quasi-public goods. The state should adopt the mechanism of policy compensation or market compensation. The policy compensation mainly settles the problem of no electricity in remote mountainous areas; enhance the standard of the downstream of the hydropower stations, take measures of cash subsidy or discount interest loan to reduce investors' costs. The market mechanism is taken to reduce the environmental pollution resulting from fuel for power generation. It can be implemented by the way of pollution emission indexes and quota system on clean energy. The power stations may transact pollution-emission indexes through market indicators, and the hydropower stations may transfer clean-energy quota to the power plants through market.

\subsection{Regulate the Decision-Making Mechanism of Grassroots-Level Governments}

The major externality of water energy resource development is the effect of public living using of water and water environment change. In the principle of collective will, the policy scheme should be dealt with on the basis of the decision-making of village committee through discussion and vote of the villagers' representative. However, a lot of the village committees have no administrative authority at all, let alone the exertion of public power. Therefore, it is necessary to regulate the decision-making mechanism of grassroots-level governments, so as to ensure the necessary administrative expenditures of village collective, condense feelings of the village-level cadres, resolve conflicts between investors and villagers.

\section{The Ecological Compensation Policy of Basin Ecological Water}

Ecological compensation of basin water refers to "The government and favored area of lower reaches give economic compensation for ecological benefit created by upper reaches", that is to say "In order to restore, maintain and enhance the ecological function of the ecological system, the external economy will be increased by compensating for the behavior conducive to the ecological service from the upstream area, so as to reach the aim of protection and improvement of water eco-environment." [16] The ecological compensation system is carried out primarily by setting ecological flows. In the process of water energy resources development, it inevitably causes zero flow of local rivers and change of river flow, which is related to the current development mode and cannot be eliminated. It is through eco-compensation that can minimize the environmental effects as possible.

\subsection{Establish Effective Reward Institution of Water Right}

After completion of hydropower station, the flow in the rivers of mountain can be controlled through engineering measures and ecological self-rehabilitation. The flow of channel in the specific dry season changes in right direction to improve the state of the natural water flow. Concrete measures include as follows: The government compulsorily determines the ecological flow and ensures the implementation of ecological engineering measures, rules and regulations. On the other hand, through negotiated contract, the above aim can be reached too. Mandatory ecological flow compensation plus consultative compensation flow equals to improvement of the ecological environment. In 2001, the Yiwu city and the Dongyang city, located in the upstream and downstream of Jinhuajiang river in Zhejiang province, signed a water-right transferring agreement, which become China's first case of water rights transactions through market mechanism.[16] The Dongyang city transferred the permanent use-right of Hengjin reservoir of $50,000,000 \mathrm{~m}^{3}$ to the Yiwu City at the price of RMB 4 yuan per $\mathrm{m}^{3}$. So the Yiwu City invests 200 million yuan one time to purchase the right to use, while the original ownership unchanged, and the Yiwu city paid comprehensive management-fees at RMB 0.1 yuan per $\mathrm{m}^{3}$ according to the actual current-year water supply.

\subsection{Establish Unified System of Configuration of Basin Water Resources}

The scheduling right is clear about reservoir of state power plant in flood period. Water level control must obey the dispatch of water or flood control department. As for the hydropower station reservoir carrying out compensable transfer, since the use rights was defined as private property rights, the actual treatment will be different. But the basic principle is that the private interests should be subject to public interest when human right of life is under threat. The water resources property right, regardless of public ownership or private property right must accept the nation's dispatch. Such systems should acquire the promise in the initial transfer contract of water rights. As to water consumption of environment, during 
the drought dry season, it is particularly important for government to posses the dispatching right of reservoir. Only in this way, should the water consumption of ecological environment be improved.

\subsection{Study and Determine the Minimum Ecological Flow}

The significance of minimum ecological flow is to maintain the continuity of the river, which is the necessary condition for the effective maintenance of river morphology and is favorable for some of the aquatic organisms to adapt to the adverse ecological environment in the dry season as soon as possible. Once below this flow, the river will face the danger of cutoff or dry up, and the self-survival function of the river will be damaged. [18] Therefore, it is very important to research on minimum ecological flow, which is beneficial to maintaining the integrity of the river of the lower reaches of the river and restoring its unique function and ecological security. [19] Ecological flow is a range of value including the maximum ecological flow and minimum ecological flow. Because the construction of hydropower stations in general can reduce the negative impact of the floods, control water flow, and have a positive externality, which makes allocation of water resources conduce to the achievement of Qmin-Qmax. Owing to less water coming during the dry season, the construction of hydropower stations will aggravate the scarcity of water resources. So the river flow will be less than Qmin away from the range of Qmin-Qmax. In such a way, the ecological crisis of channel will happen. For example [18], based on the viewpoint of maintenance of the critical survival condition of river water and characteristics of geomorphology of control sections of different channels of the Liaohe River, the rates of minimum ecological discharge of the river channels were calculated and their characteristics were analyzed from the aspect of water quantity, which is the most fundamental factor of ecological water demand. As a result, the control criterion for minimum discharge of the Liaohe River was deduced.

\subsection{Establish Contract Mechanism between Enterprise and Representative of Ecological Interests}

As the above has established the specific ecological river flow, at this stage, the future operation mode of the reservoir should be set. That is to make the future specific mode of water discharge under certain conditions. For example, in the southern area, it is not necessary to input the ecological flow in the rain-abundant spring. On the contrary, in the rain-scarce summer, much more water flow should be input. In the contract, one signing party is the hydropower plant; the other is the management de- partments of the river or the chief representatives of the downstream villagers. Furthermore, the requirements of water quality and water quantity of different river reaches, which is the core of the basin water ecological compensation [20], must be clarified in the contract, and meanwhile the compensation responsibility with or without reaching the standards must be defined clearly, too.

\section{Conclusions}

Ecological compensation mechanism, through adjusting the relationship of relevant groups between environment and economic benefits, encourages ecological environmental protection, and promotes equity and development between regions and social groups. China's current system of water resources management has certain gaps with the requirements of sustainable use of water resources. Meanwhile, the management system of water energy resources is directly related to the management system of water resources. At present, among the subjects of water resources allocation in China, there are too many interest subjects exercising administrative functions on behalf of the government's interests, such as environmental protection departments, plans, water conservancy, urban construction, land, forestry and other departments. Thus, it is necessary to integrate watermanagement functions of various government- departments, and establish a scientific and efficient watermanagement system, so as to clearly define the interest subject "the state". Although water energy resources management is an integral part of water resources management, the undefined management responsibility of water energy is the main problem in the water energy resources management currently. On the basis of practical experience, the water energy resources management should be brought into the category of water resources management. The water energy resources management mechanism of unified management and graded responsibility should be established at the national level. The right of planning, use and development should be defined clearly to guarantee the specification, the orderliness and rational development. So, it is important to exert the complementary function between market compensation and government compensation by the means of economic compensation, and to establish the ecological compensation policy of basin ecological water, which is beneficial to coordinating the stakeholders' interests of cross-region or inter-basin. No matter what kind of policy, it is a constantly perfected process, which will induce us to explore and study continuously it.

\section{References}

[1] W. H. Li, "The eco-compensation mechanism \& policy suggestion,” High-Technology \& Industrialization, No. 9, pp. 37-40, 2007. 
[2] G. D. Hua, "A matrix model of forest ecological services compensation [J]," Hunan Forestry Science and Technology, 31(4): pp. 31-33, 2004.

[3] G. Y. Zhou, “Theory and practice of ecological public welfare forest compensation [M],” Beijing: Meteorological Press, 2000.

[4] R. G. Luo and Z. P. Ding, "Rectify externality and the compensation system of reforestation in the upper Yangtze River valley [J],” Journal of Wuhan University of Technology, 25(7): pp. 84-87, 2003.

[5] M. H. Yang, "Argument on externality correction and the establishment of compensation system for reforestation [J],” Finance and Economics, (3): pp. 6-9, 2002.

[6] J. Zhao, H. L. Qin, and X. L. Fang, "Ecological compensation mechanism and policy proposals for songhuaba watershed conservation area, Kunming [J]," Journal of Southwest Forestry College, 28(4): pp. 137-141, 2008.

[7] X. L. Shi, "Study on eco-compensation mechanism based on major function oriented zoning in china [J]," World Economic Outlook, (4): pp. 80-85, 2008.

[8] Y. P. Zhang, "Fiscal policy for establishing a mechanism for ecological compensation [J]," Natural Resource Economics of China, (8): pp. 21-23, 47, 2007.

[9] W. Y. Shao, "A research on Compensation and Compensation Mechanism in Hydraulic Engineering [J]," Haihe Water Resources, (4): pp. 29-30, 2001.

[10] Z. Ye, “The sustainable development of small hydropower in Zhejiang Province(1)-study on the system of market allocation of developing right of water power resources [J]," Rural Hydropower \& Electrigicatian in China, (4/5): pp. 34-39, 2005.

[11] Y. P. Zhang, "Fiscal policy for establishing a mechanism for ecological compensation [J],” Natural Resource
Economics of China, (08): pp. 22-23, 2007.

[12] F. J. Liu and X. K. Li, "A research of the ecosystem market compensating system [J]," Journal of Yunnan Finance \& Economics University, 20(01): pp. 38-40, 2005.

[13] F. J. Liu and H. M. Qi, "A research of the eco-system market compensating system [J]," Journal of Kunming University of Science and Technology, 5(01): pp. 25-28, 2005.

[14] Y. X. Ge, F. F. Wu, B. B. Wang, and L. J. Liang, "Valley ecological compensation: The comparison and selection between the government compensation and the market compensation [J]," Journal of Shandong Agricultural University (Social Science Edition, (04): pp. 48-53, 2007.

[15] S. L. Zeng and Y. L. Ren, "Study on ecological compensation mechanism in developing the hydropower resources in Sichuan, China [J],” Journal of Sichuan University of Science \& Engineering (Natural Science Edition), 19(06): pp. 101-107, December 2006.

[16] Z. Ye, "The sustainable development of small hydropower in Zhejiang Province(2)-the externality of water power resources development and compensation mechanism [J],” Rural Hydropower \& Electrigicatian in China, (6/7): pp. 4-7, 2005.

[17] X. Y. Li, "Study on basin water ecological compensation in the perspective of eco-civilization [J]," Rural Economy, (09): pp. 59-62, 2008.

[18] F. Su, M. J. Chen, Z. C. Dong, and Z. X. Xu, "Minimum ecological discharge of Liaohe River [J],” Journal of Hohai University (Natural Sciences), 34 (02): pp. 136-138, 2006.

[19] Z. X. Ye, Y. L. Chen, and W. H. Li, "Minimum ecological discharge of dried-up riverway of lower reaches of tarim river [J]," The Development of Natural Science, 18 (5): pp. 135-735, 2008.

[20] J. N. Wang, J. Wan, and H. Y. Zhang, "Some cognition on Chinese ecological compensation mechanism and policy [J],” Environmental Protection, No. 10: pp. 24-28, 2006. 